\title{
Lachnospira pectinoschiza sp. nov., an Anaerobic Pectinophile from the Pig Intestine
}

\author{
N. A. CORNICK,,${ }^{1,2}$ N. S. JENSEN, ${ }^{1}$ D. A. STAHL, ${ }^{3}$ P. A. HARTMAN,${ }^{2}$ AND M. J. ALLISON ${ }^{1 *}$ \\ Physiopathology Research Unit, National Animal Disease Center, Agricultural Research Service, \\ U.S. Department of Agriculture, ${ }^{1}$ and Department of Microbiology, Immunology and Preventive Medicine, \\ Iowa State University, ${ }^{2}$ Ames, Iowa 50010, and Department of Veterinary Pathobiology and Microbiology, \\ University of Illinois at Champaign-Urbana, Urbana, Illinois $61801^{3}$
}

\begin{abstract}
Pectinophiles are bacteria that utilize pectin and only a few related compounds as substrates. Obligately anaerobic pectinophiles have been isolated from the intestinal tracts and gingivae of humans and from the rumina of cattle. We isolated three strains of pectinophilic bacteria from colonic contents of pigs but were unable to isolate pectinophiles from the rumen contents of four sheep, even when the animals were fed a high-pectin diet. The pectinophiles isolated from pigs were strictly anaerobic, motile, gram-positive rods $(0.36$ to 0.56 by 2.4 to $3.1 \mu \mathrm{m}$ ). Pectin, polygalacturonic acid, and gluconate were the only substrates that supported rapid growth. All three strains grew slowly on either lactose or cellobiose and fermented fructose after a lag of several days. Pectin was degraded by means of an extracellular pectin methylesterase and a $\mathrm{Ca}^{2+}$-dependent exopectate lyase. A comparison of the 16S rRNA sequences of these isolates with the 16S rRNA sequences of other gram-positive bacteria revealed a specific relationship with Lachnospira multipara (level of similarity, 94\%). The Gram reaction, formation of spore-like structures, and the utilization of lactose and cellobiose differentiated the pig isolates from previously described pectinophiles. The pig isolates represent a previously undescribed species of the genus Lachnospira, for which we propose the name Lachnospira pectinoschiza.
\end{abstract}

Most pectin-degrading bacteria in gastrointestinal habitats are able to utilize a diversity of substrates. However, several bacteria isolated from human intestinal tracts (15) and gingivae $(34,38)$ and one spirochete isolated from a bovine rumen (41) are pectinophiles since they ferment only pectin and a few related compounds. We hypothesized that other pectinophiles may be present in gastrointestinal habitats but have not been isolated because pectin generally has not been included in the complex media used to enumerate microbial populations. In this paper we describe our search for rumen pectinophiles and characterize pectinophiles that we isolated from the large intestines of swine.

(A preliminary report of this work has been presented previously [7a]).

\section{MATERIALS AND METHODS}

Samples from animals. Four sheep (weight, 27 to $76 \mathrm{~kg}$ ) were fed a diet consisting of alfalfa (ad libitum) and Sheep Feed 590 (Ralston Purina, St. Louis, Mo.) (900 g per animal per day). After 1 month the diet fed to two animals was changed to sugar beet pulp (American Sugar Co., Moorehead, Minn.) (600 g per animal per day) and wheat straw (ad libitum). Following a 2-week stabilization period for each diet, rumen fluid was collected through a rumen cannula approximately $4 \mathrm{~h}$ after feeding.

Five pigs (weight 15 to $30 \mathrm{~kg}$ ) were fed a diet consisting of corn $(65 \%)$ and soybean meal $(30 \%)$. After 2 to 4 weeks, the animals were sacrificed and the cecal contents were collected.

Samples were processed within $0.5 \mathrm{~h}$ of collection. Whole samples were homogenized with a Waring blender under a $\mathrm{CO}_{2}$ atmosphere for $1 \mathrm{~min}$. An $11-\mathrm{g}$ portion was mixed with $99 \mathrm{ml}$ of anaerobic dilution solution (andil) (5) and homoge-

\footnotetext{
${ }^{*}$ Corresponding author.
}

nized under a $\mathrm{CO}_{2}$ atmosphere for an additional $1 \mathrm{~min}$, and serial 10 -fold dilutions in andil were prepared.

Media and physiological tests. Medium 134-11 contained (per liter) $360 \mathrm{ml}$ of energy-depleted rumen fluid (2), $1.6 \mathrm{~g}$ of $\mathrm{K}_{2} \mathrm{HPO}_{4}, 1.6 \mathrm{~g}$ of $\mathrm{KH}_{2} \mathrm{PO}_{4}, 3.2 \mathrm{~g}$ of $\left(\mathrm{NH}_{4}\right)_{2} \mathrm{SO}_{4}, 3.2 \mathrm{~g}$ of $\mathrm{NaCl}, 0.3 \mathrm{~g}$ of $\mathrm{MgSO}_{4} \cdot 7 \mathrm{H}_{2} \mathrm{O}, 0.15 \mathrm{~g}$ of $\mathrm{CaCl}_{2} \cdot 2 \mathrm{H}_{2} \mathrm{O}, 1.0 \mathrm{~g}$ of cysteine $\mathrm{HCl} \cdot \mathrm{H}_{2} \mathrm{O}, 0.001 \mathrm{~g}$ of resazurin, $4.0 \mathrm{~g}$ of $\mathrm{Na}_{2} \mathrm{CO}_{3}$, and $2.5 \mathrm{~g}$ of ethanol-washed (17) polygalacturonic acid (PGA) (Sigma Chemical Co., St. Louis, Mo.). Modified BGD medium (15) contained (per liter) $2.0 \mathrm{~g}$ of $\mathrm{KH}_{2} \mathrm{PO}_{4}, 6.0$ $\mathrm{g}$ of $\mathrm{K}_{2} \mathrm{HPO}_{4}, 2.5 \mathrm{~g}$ of $\mathrm{MgSO}_{4} \cdot 7 \mathrm{H}_{2} \mathrm{O}, 0.15 \mathrm{~g}$ of $\mathrm{CaCl}_{2} \cdot 2 \mathrm{H}_{2} \mathrm{O}, 0.02 \mathrm{~g}$ of $\mathrm{FeSO}_{4} \cdot 7 \mathrm{H}_{2} \mathrm{O}, 1.4 \mathrm{~g}$ of $\left(\mathrm{NH}_{4}\right)_{2} \mathrm{SO}_{4}$, $1.0 \mathrm{~g}$ of cysteine $\mathrm{HCl} \cdot \mathrm{H}_{2} \mathrm{O}, 0.001 \mathrm{~g}$ of resazurin, $4.0 \mathrm{~g}$ of PGA, $1.0 \mathrm{~g}$ of $\mathrm{NaHCO}_{3}$, and $2.0 \mathrm{~g}$ of yeast extract. Roll tubes contained $2 \%$ agar. The carbohydrates and amino acids tested as potential substrates were added as filter-sterilized solutions to a final concentration of $0.2 \%$ to medium PF base (15) without PGA. All media were prepared and dispensed anaerobically under a $\mathrm{CO}_{2}$ (medium 134-11), $\mathrm{N}_{2}-\mathrm{CO}_{2}(90: 10)$ (medium PF), or $\mathrm{N}_{2}$ (BGD medium) atmosphere.

Triplicate roll tubes were inoculated with $0.2-\mathrm{ml}$ portions of diluted gastrointestinal contents. Total counts were determined by using medium CCA (2) and medium CCA containing $0.2 \%$ PGA. Pectin-utilizing bacteria were enumerated by using medium 134-11 and medium PF. The tubes were incubated at $39^{\circ} \mathrm{C}$ for $72 \mathrm{~h}$. Colonies were counted, and about 20 colonies were randomly picked from medium 134-11 and medium PF preparations and inoculated into medium 134-11 broth and medium PF broth, respectively. After 24 to $48 \mathrm{~h}$, the isolates were examined by using the Somogyi-Nelson assay (28) for the production of reducing sugars from PGA. Isolates which utilized glucose and/or other sugars in addition to pectin were not characterized further.

Catalase production was tested by using cells grown on medium $\mathrm{PF}$ agar plates in an anaerobic chamber (Coy Laboratories, Ann Arbor, Mich.) containing 5\% $\mathrm{CO}_{2}-10 \%$ $\mathrm{H}_{2}-85 \% \mathrm{~N}_{2}$ atmosphere. The plates were exposed to room atmosphere for $30 \mathrm{~min}$ prior to the addition of $3 \% \mathrm{H}_{2} \mathrm{O}_{2}$. 
Medium PF broth supplemented with $0.1 \% \mathrm{KNO}_{3}$ but lacking cysteine and resazurin was used to determine nitrate reduction. Medium PF broth supplemented with $12 \%$ gelatin and medium PF broth supplemented with $2 \%$ oxgall were used to test for gelatin hydrolysis and bile tolerance, respectively. Medium PF broth supplemented with $0.1 \%$ esculin was observed under long-wavelength (366-nm) UV light for fluorescence of intact esculin (11).

Microscopy. Spore formation was determined after cultures were grown on medium PF and on egg yolk agar (EYA) supplemented with $0.4 \%$ PGA. The cultures were incubated at 30 and $39^{\circ} \mathrm{C}$ for 2 weeks. Spore stains were prepared by the Schaeffer-Fulton method (10). Resistance to heat (13) and resistance to ethanol (18) were also determined.

Log-phase cells grown in medium PF were harvested and washed with distilled water. Negative stains were prepared with $0.5 \%$ phosphotungstic acid (35).

Cells to be sectioned for electron microscopy were grown in BGD medium (15) to log phase or on EYA slants at $30^{\circ} \mathrm{C}$ for 7 days. The cells were harvested and fixed for $2 \mathrm{~h}$ in $2.5 \%$ glutaraldehyde in $0.1 \mathrm{~N}$ sodium cacodylate buffer. The fixed cells were embedded in $2 \%$ agar, dehydrated in ethanol, and infiltrated with resin. Ultrathin sections (thickness, approximately $60 \mathrm{~nm}$ ) were cut with a diamond knife, stained with $2 \%$ uranyl acetate and lead citrate, and then examined with a Philipps model 410 transmission electron microscope.

Fermentation products. Butyl esters (33) of volatile fatty acids were analyzed with a gas chromatograph (model 5890; Hewlett-Packard, Avondale, Pa.) equipped a hydrogen flame ionization detector. This instrument was also used at $40^{\circ} \mathrm{C}$ to detect alcohols. A series 580 gas chromatograph (Gow Mac, Bridgewater, N.J.) equipped with Pora Pak Q 80/100-mesh columns and a thermal conductivity detector was used to measure $\mathrm{H}_{2}$ and $\mathrm{CO}_{2}$ concentrations in headspace gases of cultures grown on modified BGD medium under an $\mathrm{N}_{2}$ atmosphere. After acidification $(0.5 \mathrm{ml}$ of $6 \mathrm{~N} \mathrm{HCl}$ per 20 $\mathrm{ml}$ ), samples were removed from sealed culture tubes with a gas-tight syringe and injected into the sample loop $(0.5 \mathrm{ml})$. Helium was the carrier gas.

Protein profiles. Proteins were separated by denaturing polyacrylamide gel electrophoresis (PAGE), using the discontinuous buffer system of Laemmli (19), a 4\% stacking gel, and a $12 \%$ separating gel. Proteins were stained with Coomassie blue R-250.

Long-chain fatty acids. Long-chain fatty acids were extracted from whole cells grown in $300 \mathrm{ml}$ of medium PF. Cell pellets were lysed at $100^{\circ} \mathrm{C}$ in $2.5 \mathrm{ml}$ of $2 \mathrm{~N} \mathrm{HCl}$ for $16 \mathrm{~h}$. Chloroform $(2.5 \mathrm{ml})$ was added to partition the lysates. After $1.5 \mathrm{ml}$ of methanol- $\mathrm{HCl}(11: 1)$ was added, the chloroform extracts were heated for $30 \mathrm{~min}$ at $55^{\circ} \mathrm{C}$. The samples were washed three times with water and then evaporated to dryness under $\mathrm{N}_{2}$ (1). The esters were resuspended in hexane and analyzed with a Hewlett-Packard model 5890 gas chromatograph. The column temperature was increased at a rate of $4^{\circ} \mathrm{C} / \mathrm{min}$ between 150 and $240^{\circ} \mathrm{C}$. The peaks were compared with the peaks produced by known standards, but no additional tests to positively identify individual fatty acids were performed.

G+C content of DNA. Cell pellets were lysed by the method of Hull et al. (14), and the DNA was isolated by $\mathrm{CsCl}$ gradient centrifugation. The $\mathrm{G}+\mathrm{C}$ content was calculated by the thermal denaturation method (24), using a Gilford Response II spectrophotometer (Ciba Corning Diagnostic Corp., Oberlin, Ohio) equipped with a thermoprogrammer. Escherichia coli ATCC 14763 (G+C content, $51.4 \mathrm{~mol} \%)$ was used as a control.
Pectinolytic enzymes. Extracellular enzymes in the culture supernatant were partially purified by acetone precipitation by using the procedure of Weber and Canale-Parola (38). Pectate lyases and polygalacturonases were detected by using the thiobarbituric acid assay (15) and the SomogyiNelson reducing sugar assay (28). Protein concentrations were measured by using a modification of the assay of Lowry et al. (31) and bovine serum albumin as the standard. Pectin methylesterase activity was assayed by the hydroxamic acid reaction (25).

The oligomers of PGA produced by the partially purified enzyme preparation were separated and identified by thinlayer chromatography $(15)$. The reaction mixture $(30 \mu \mathrm{l})$ was spotted onto type E-13255 cellulose plates (Eastman Kodak, Rochester, N.Y.), which were developed twice in ethyl acetate-acetic acid-water $(4: 2: 3, \mathrm{vol} / \mathrm{vol} / \mathrm{vol})$ at $25^{\circ} \mathrm{C}(23)$. The plates were sprayed with the $p$-anisidine reagent $(7)$ and heated at $100^{\circ} \mathrm{C}$ for 5 to $10 \mathrm{~min}$. D-Galacturonic acid, digalacturonic acid, and trigalacturonic acid (Sigma Chemical Co.) were used as standards.

Sequencing of 16S RNA. The almost complete 16S rRNA sequence of each isolate was determined by using RNA template sequencing. Total nucleic acid (primarily RNA) was extracted from approximately 50 to $100 \mathrm{mg}$ of cells with hot phenol (30), and the nucleotide sequence was determined by the dideoxynucleotide method, using reverse transcriptase (21). Three universal sequencing primers (21) and four additional oligonucleotide primers were used to determine nearly complete $16 \mathrm{~S}$ rRNA sequences $(20,26)$. Only the three universal sequencing primers were used for the characterization of Lachnospira multipara. In addition to the standard deoxynucleotide reaction experiments, reaction experiments in which inosine was substituted for guanosine were performed with all sequencing primers. The inclusion of inosine resolved many sequencing gel ambiguities caused by premature termination and band compression in GC-rich regions of the transcripts.

Sequence analysis. 16S rRNA sequences were aligned on the basis of conserved features of primary and secondary structures $(36,38)$. The sequences of strain $150-1^{\mathrm{T}}(\mathrm{T}=$ type strain), L. multipara D32 and 40, and Roseburia cecicola were determined in this study. Other sequences used for analysis were obtained from the RNA Database Project (29). These sequences were the sequences of Clostridium aminovalericum ATCC 13725, Clostridium oroticum ATCC 13619, Clostridium symbiosum ATCC 14940, Clostridium coccoides ATCC 29236, Streptococcus hansenii ATCC 27752, Clostridium barkeri ATCC 25849, Clostridium pasteurianum ATCC 6013, Clostridium ramosum 113-1, Clostridium innocuum B-3, Lactobacillus casei subsp. casei ATCC 393, and Bacillus subtilis. Levels of sequence similarity were calculated by using only nucleotide positions at which alignment in all of the sequences compared was unambiguous. The levels of similarity were converted to evolutionary distances by the method of Jukes and Cantor (16). A phylogenetic tree was constructed on the basis of inferred evolutionary distances by using the algorithm of DeSoete (8). In addition to the evolutionary distance method, relationships were examined by using the DNABOOT program of PHYLIP (phylogeny inference package) (12); this program implements the bootstrap method of placing confidence limits on phylogenies by using parsimony.

Nucleotide sequence accession numbers. The GenBank accession numbers for the sequences determined in this study are as follows: strain 150-1 , L14675; L. multipara D32, L14674; L. multipara 40, L14673; and R. cecicola, L14676. 


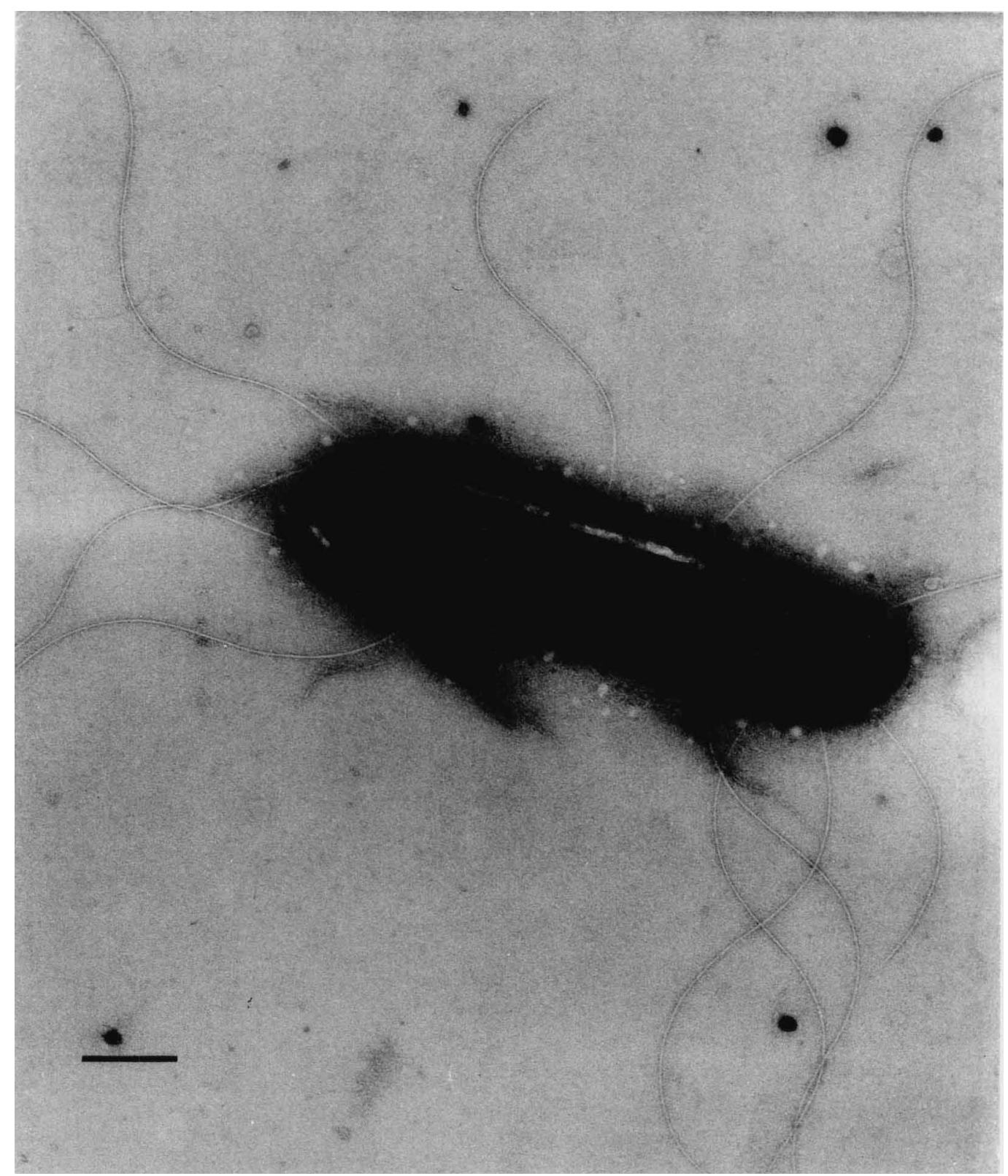

FIG. 1. Electron micrograph of a strain $131-8$ cell stained with $0.5 \%$ phosphotungstic acid. The culture was grown to mid-log phase in medium PF. Bar $=0.5 \mu \mathrm{m}$.

\section{RESULTS}

Isolation. Six samples of rumen contents from four sheep fed an alfalfa diet were cultured for pectinophiles. Of 177 isolates screened, $66(37 \%)$ were pectinolytic. These bacteria were not pectinophiles, however, because they utilized glucose and/or other sugars in addition to PGA. Three samples of rumen fluid from sheep fed beet pulp and wheat straw yielded a higher percentage of pectinolytic isolates (64\%); however, no pectinophiles were isolated.

One fecal and four cecal samples were cultured from five pigs. Of 93 isolates tested, $12(13 \%)$ were pectinolytic. Three additional strains, each isolated from a different animal and all isolated from roll tubes containing medium 134-11 that had been inoculated with $2 \times 10^{-7} \mathrm{ml}$ of cecal contents, were pectinophilic. These strains were designated strains 122-19 (fecal), 131-8 (cecal), and 150-1 ${ }^{\mathrm{T}}$ (cecal).

Phenotypic description. All three pectinophilic isolates were strictly anaerobic, gram-positive rods ( 0.36 to 0.56 by 2.4 to $3.1 \mu \mathrm{m}$ ) that grew at temperatures ranging from 30 to $45^{\circ} \mathrm{C}$. The peritrichous cells were motile by means of 6 to 18 flagella (Fig. 1). Pectin, PGA, D-gluconate, cellobiose, and lactose were fermented. D-Fructose was utilized after a lag period of 2 to 6 days. D-Galacturonic acid, the monomeric unit of PGA, was not utilized by any of the strains. Other carbohydrates and amino acids were not fermented. Growth on gluconate, pectin, and PGA was rapid; the estimated population doubling time was 55 min when PGA was the substrate. The doubling times were 4 to $6 \mathrm{~h}$ when fructose or lactose was used as the substrate and 7 to $10 \mathrm{~h}$ when 
TABLE 1. End products formed by strain $150-1^{\mathrm{T}}$ grown on different substrates

\begin{tabular}{lcccc}
\hline \multirow{2}{*}{ Substrate } & \multicolumn{4}{c}{ Concn $(\mu \mathrm{mol} / \mathrm{ml}$ of culture broth) of: } \\
\cline { 2 - 5 } & Formate & Acetate & Ethanol & Methanol \\
\hline PGA $^{a}$ & $7^{b}$ & 9 & $<1$ & 0 \\
Pectin $^{c}$ & 7 & 6 & $<1$ & 5 \\
Lactose & 8 & 3 & 15 & 0 \\
Cellobiose & 7 & 3 & 12 & 0 \\
Fructose & 8 & 3 & 11 & 0 \\
\hline
\end{tabular}

${ }^{a}$ Strain $150-1^{\mathrm{T}}$ was grown in modified BGD medium containing $0.2 \%$ PGA.

${ }^{b}$ Mean of three samples.

${ }^{c}$ Strain $150-1^{\mathrm{T}}$ was grown in medium PF containing $0.2 \%$ carbohydrate. cellobiose was used. The major end products of PGA fermentation by strain $150-1^{\mathrm{T}}$ were formate and acetate (Table 1). Ethanol and $\mathrm{CO}_{2}(2 \mu \mathrm{mol} / \mathrm{ml})$ were also formed. Methanol was produced when pectin was fermented. When lactose, cellobiose, or fructose was utilized, ethanol was the most abundant product. Similar data were obtained for strains $122-19$ and 131-8. Tests for catalase activity, nitrate reduction, gelatin hydrolysis, $\mathbf{H}_{2}$ production, and esculin hydrolysis were negative. Bile did not inhibit growth. Sporelike structures were detected by light microscopy in stained cell preparations of all three strains that had been cultured for 14 days at $30^{\circ} \mathrm{C}$ on EYA supplemented with $0.4 \%$ PGA. Inclusions which appeared to be endospores were also observed in electron micrographs of ultrathin sections of cells grown on EYA (Fig. 2). However, no survivors were detected after the cultures had been exposed to temperatures of 60 to $80^{\circ} \mathrm{C}$ for $5 \mathrm{~min}$ or to $50 \%$ ethanol for $45 \mathrm{~min}$. These
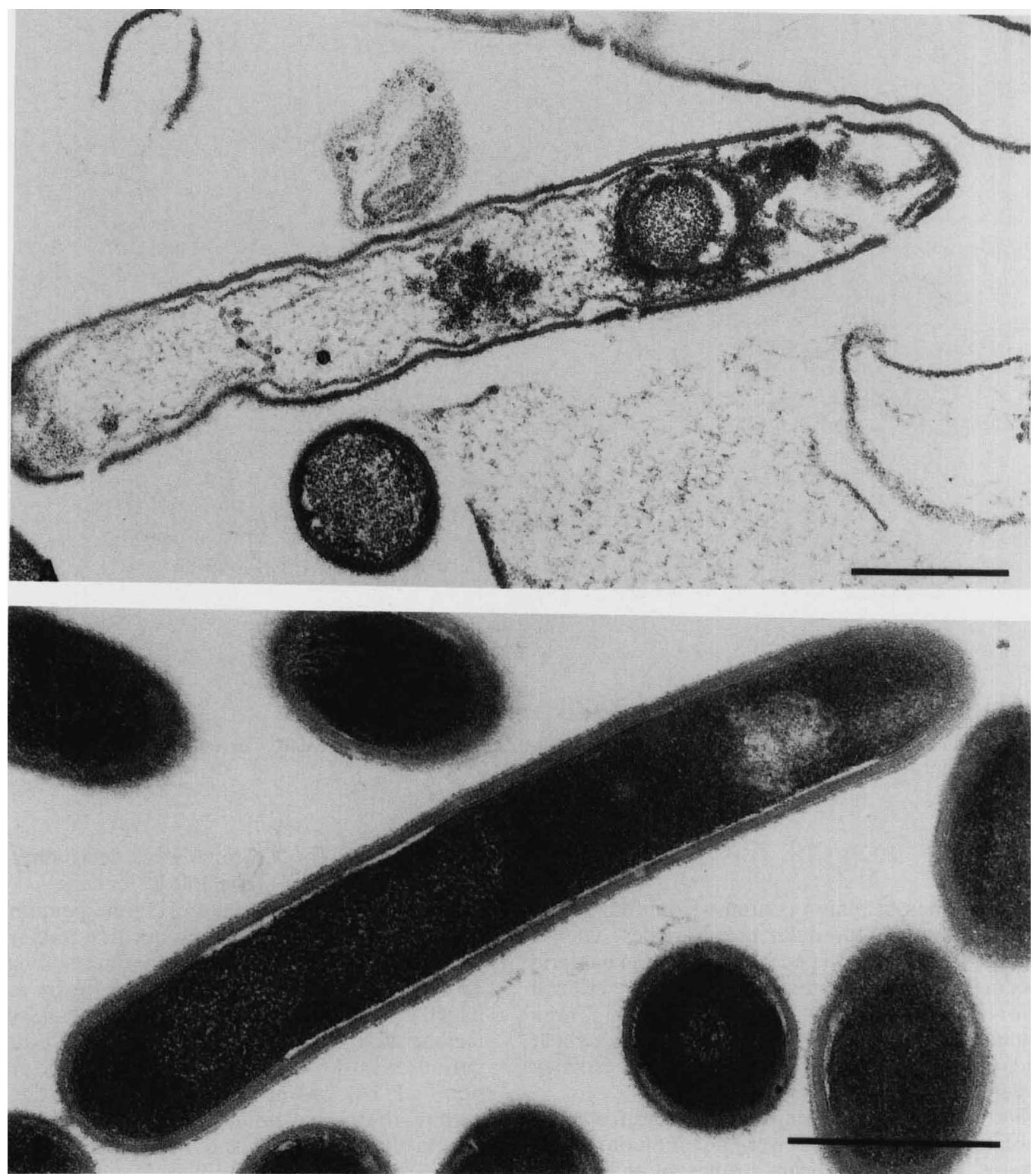

FIG. 2. (A) Electron micrograph of a thin section of a strain 122-19 culture grown on EYA for 7 days. Bar $=0.5 \mu \mathrm{m}$. (B) Electron micrograph of a thin section of a strain 131-8 culture grown to exponential phase in BGD medium. Bar $=0.5 \mu \mathrm{m}$. 
TABLE 2. Specific activities of extracellular pectate lyase with and without EDTA and $\mathrm{CaCl}_{2}$

\begin{tabular}{|c|c|c|c|}
\hline \multirow{2}{*}{ Substrate prepn } & \multicolumn{3}{|c|}{$\begin{array}{c}\text { Sp act }\left(\mathrm{U} \mathrm{min}^{-1} \mathrm{mg} \text { of }\right. \\
\text { protein }\end{array}$} \\
\hline & $\begin{array}{l}\text { Strain } \\
122-19\end{array}$ & $\begin{array}{c}\text { Strain } \\
131-8\end{array}$ & $\begin{array}{l}\text { Strain } \\
150-1^{T}\end{array}$ \\
\hline PGA & 2.7 & 3.2 & 2.4 \\
\hline PGA + 0.5 mM EDTA & 0.2 & 0.3 & 0.2 \\
\hline $\mathrm{PGA}+0.5 \mathrm{mM}$ EDTA $+1 \mathrm{mM} \mathrm{CaCl}_{2}$ & 2.5 & 3.6 & 2.6 \\
\hline Pectin $^{b}$ & 0.8 & 1.3 & 1.4 \\
\hline
\end{tabular}

a One unit was defined as the amount of enzyme that resulted in an increase in $A_{548} 1.0$ in the thiobarbituric acid assay (15).

$b$ Pectin was substituted for PGA in the reaction mixture.

structures were not observed in cells grown on medium PF under similar conditions. The sodium dodecyl sulfate-PAGE profiles of total cell proteins from the three isolates were similar. The profiles of methyl esters of long-chain fatty acids extracted from whole cells were also similar, although the quantities of individual acids varied among strains. A fatty acid with the same retention time as palmitic acid (16:0) was the predominant fatty acid present. A second peak correlated with the retention time of myristic acid (14:0). The average $\mathrm{G}+\mathrm{C}$ contents of DNA preparations, from two different determinations, were $42 \mathrm{~mol} \%$ for strains $122-19$ and $150-1^{\mathrm{T}}, 45 \mathrm{~mol} \%$ for strain $131-8$, and $32 \mathrm{~mol} \%$ for $L$. multipara D32.

Pectinolytic enzymes. Dialyzed enzyme preparations from culture supernatants of all three strains produced reducing sugars from PGA at $\mathrm{pH} 8.5$ but not at $\mathrm{pH}$ 5.5. The thiobarbituric acid assay was positive. This indicated that pectate lyases that formed unsaturated end products and had alkaline $\mathrm{pH}$ optima (32) were present. The addition of EDTA to the reaction mixture resulted in a 10-fold decrease in enzyme activity (Table 2). Addition of $\mathrm{Ca}^{2+}$ to a reaction mixture containing EDTA restored enzyme activity. These enzymes were similar to other pectate lyases in that calcium ions were required for optimal activity. The relative activities of the pectate lyases recovered from culture supernatants were greater when PGA was the substrate than when pectin was the substrate (Table 2).

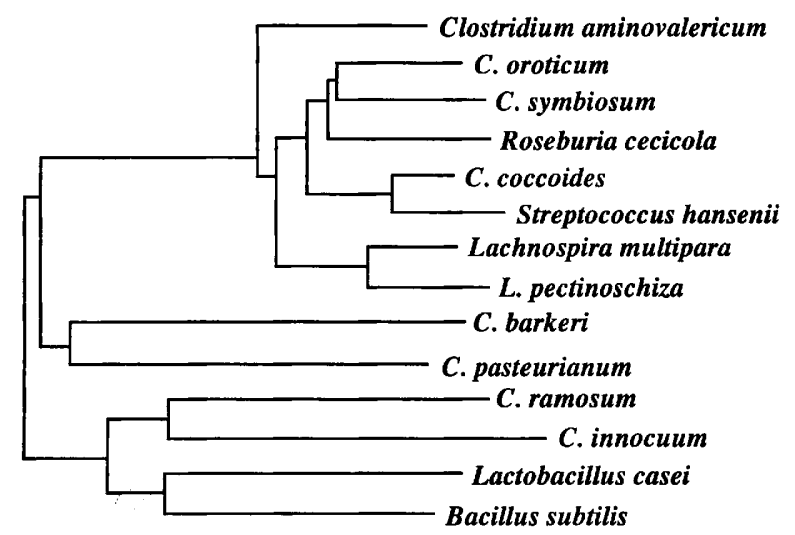

$5 \%$

FIG. 3. Phylogenetic tree of $L$. pectinoschiza and other grampositive bacteria based on 16S rRNA sequence comparisons. Bar = 0.05 estimated nucleotide change per position.

When strains were grown in medium PF containing pectin, production of pectin methylesterase was detected by the hydroxamic acid reaction (data not shown) and by the formation of methanol in culture supernatants.

Analysis of the end products obtained from PGA by thin-layer chromatography indicated that a dimer was the initial and major end product formed. After extended incubation $(2 \mathrm{~h})$, a trimer was also produced. The appearance of the dimer early in the reaction and the failure to find oligomers of different sizes as early products indicated that PGA was cleaved from the terminal end by an enzyme with an exo pattern of action.

16S rRNA sequence analysis. A similarity matrix showing the relationships among strain $150-1^{\mathrm{T}}$ and 13 other grampositive bacteria is shown in Table 3 . A phylogentic tree constructed from the data in Table 3 is shown in Fig. 3. The sequences in the assemblage marked by the divergence of $C$. aminovalericum constitute a monophyletic group (100\% of the bootstrapped samples). Within this group, a monophyletic subset composed of strain $150-1^{\mathrm{T}}$ and $L$. multipara was revealed by both evolutionary distance analysis and boot-

TABLE 3. 16S rRNA sequence similarity matrix for strain $150-1^{\mathrm{T}}$ and other gram-positive bacteria

\begin{tabular}{|c|c|c|c|c|c|c|c|c|c|c|c|c|c|}
\hline \multirow[b]{2}{*}{ Species } & \multicolumn{13}{|c|}{$\%$ Similarity to: } \\
\hline & 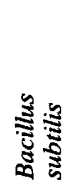 & 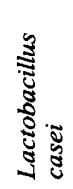 & 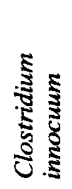 & 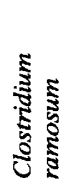 & 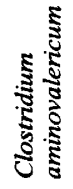 & 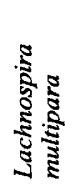 & 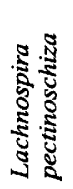 & 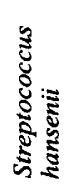 & 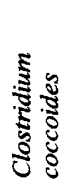 & 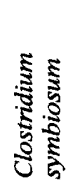 & 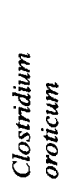 & 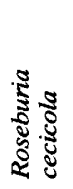 & 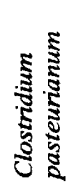 \\
\hline Lactobacillus casei & 86.7 & & & & & & & & & & & & \\
\hline Clostridium innocuum & 81.5 & 81.8 & & & & & & & & & & & \\
\hline Clostridium ramosum & 81.9 & 82.1 & 84.0 & & & & & & & & & & \\
\hline Clostridium aminovalericum & 81.5 & 81.1 & 79.8 & 81.4 & & & & & & & & & \\
\hline Lachnospira multipara & 79.2 & 79.0 & 78.8 & 79.0 & 90.0 & & & & & & & & \\
\hline Lachnospira pectinoschiza & 80.7 & 81.0 & 79.2 & 81.2 & 89.2 & 94.1 & & & & & & & \\
\hline Streptococcus hansenii & 80.0 & 79.6 & 79.2 & 80.7 & 88.9 & 87.6 & 88.3 & & & & & & \\
\hline Clostridium coccoides & 81.0 & 81.4 & 79.3 & 81.2 & 89.5 & 88.4 & 90.2 & 94.1 & & & & & \\
\hline Clostridium symbiosum & 81.0 & 81.4 & 79.6 & 80.5 & 90.1 & 89.4 & 89.6 & 89.7 & 91.2 & & & & \\
\hline Clostridium oroticum & 81.2 & 80.9 & 78.6 & 81.3 & 91.1 & 89.6 & 89.7 & 90.4 & 92.6 & 92.3 & & & \\
\hline Roseburia cecicola & 80.4 & 80.8 & 77.4 & 80.7 & 88.9 & 90.5 & 91.4 & 89.4 & 91.1 & 91.1 & 91.3 & & \\
\hline Clostridium pasteurianum & 84.3 & 83.5 & 79.2 & 80.3 & 83.7 & 80.5 & 82.4 & 82.0 & 82.5 & 82.2 & 83.4 & 81.4 & \\
\hline Clostridium barkeri & 83.9 & 81.0 & 79.7 & 79.7 & 82.5 & 80.0 & 80.7 & 81.6 & 81.5 & 80.3 & 82.0 & 79.7 & 84.0 \\
\hline
\end{tabular}


TABLE 4. Phenotypic characteristics of $L$. pectinoschiza and L. multipara

\begin{tabular}{|c|c|c|c|c|c|c|c|c|}
\hline Species & Major fatty acids & $\begin{array}{l}\text { Cell width } \\
(\mu \mathrm{m})\end{array}$ & $\begin{array}{l}\text { Cell length } \\
\qquad(\mu \mathrm{m})\end{array}$ & $\begin{array}{c}\text { Temp } \\
\text { range } \\
\left({ }^{\circ} \mathrm{C}\right)\end{array}$ & Flagella & $\begin{array}{c}\text { Colony } \\
\text { characteristics }\end{array}$ & $\begin{array}{l}\mathrm{G}+\mathrm{C} \\
\text { content } \\
(\mathrm{mol} \%)\end{array}$ & $\begin{array}{l}\text { Fermentation } \\
\text { end products }\end{array}$ \\
\hline L. pectinoschiza & $16: 0,14: 0$ & $0.4-0.6$ & $2.4-3.1$ & $30-45$ & Peritrichous & Opaque, umbonate & $42-45$ & $\mathrm{~A}, \mathrm{~F}, \mathrm{E}, \mathrm{M}, \mathrm{CO}_{2}$ \\
\hline L. multipara & $16: 0,16: 0$ ald $^{b}, 14: 0$ & $0.4-0.6$ & $2.0-4.0$ & $30-45$ & Monotrichous & Flat, filamentous & 32 & $\begin{array}{l}\mathrm{A}, \mathrm{F}, \mathrm{L}, \mathrm{E}, \mathrm{M}, \\
\quad \mathrm{CO}_{2}, \mathrm{H}_{2}\end{array}$ \\
\hline
\end{tabular}

\footnotetext{
${ }^{a}$ Fermentation end products in cultures grown in medium containing pectin. Abbreviations: A, acetate; F, formate; E, ethanol; M, methanol; L, lactate.
}

${ }^{b}$ 16-carbon saturated aldehyde.

strapped parsimony analysis (the 16S rRNA sequences of $L$. multipara D32 and 40 were identical in the sequence region determined). A monophyletic group containing $C$. coccoides and $S$. hansenii was also identified. However, the relationships among other sequences in this assemblage (Fig. 3) were not significant as determined by bootstrap analysis or stable to altered sequence composition of distance trees. For example, the specific (monophyletic) relationship between $C$. oroticum and $C$. symbiosum should not be considered significant.

\section{DISCUSSION}

The pectinophilic bacteria that we isolated from the intestinal contents of pigs were present at densities of approximately $10^{7} \mathrm{CFU} / \mathrm{ml}$ or $0.1 \%$ of the colonic population. Butine and Leedle (6) found populations containing $8 \times 10^{9}$ to $17 \times$ $10^{9} \mathrm{CFU}$ of pectin-degrading bacteria per $\mathrm{ml}$ in the colonic contents of pigs. These counts were obtained by using a medium that contained Trypticase, yeast extract, depleted rumen fluid, and pectin (22). We obtained similar colony counts with medium PF; however, no pectinophiles were isolated from this medium.

We consider our isolates pectinophiles even though they have a somewhat less restrictive range of substrates than previously described pectinophiles. Our isolates grew much more rapidly on pectin and related compounds than on fructose, lactose, or cellobiose (doubling times of $55 \mathrm{~min}$ versus 240 to $600 \mathrm{~min}$ ). The ability to utilize both lactose and cellobiose distinguishes these isolates from other pectinophiles and may serve as a survival mechanism when pectin is not present in the colon.

All three isolates produced at least two extracellular enzymes which degraded pectin, pectin methylesterase and exopectate lyase. Bacteroides pectinophilus and Bacteroides galacturonicus, two previously described pectinophiles (15), also produced extracellular pectin methylesterase and exopectate lyase. Both of the latter organisms cleaved the PGA polymer to unsaturated trimers. Treponema pectinovorum, a pectinophile present in human gingivae (38), formed extracellular pectin methylesterase and an endopectate lyase which broke PGA down to unsaturated dimers. Our strains did not produce any extracellular galacturonanase; this is characteristic of other pectinophiles as well.

Although spore-like structures were observed, there was no evidence of resistance to heating at 60 to $80^{\circ} \mathrm{C}$ or germination after exposure to $50 \%$ ethanol.

The 16S rRNA sequences of strain $150-1^{\mathrm{T}}$ and $L$. multipara indicate that these organisms are members of a closely related monophyletic group. This suggests that these organisms were derived from an ancestor that presumably occupied a niche defined, in part, by pectin hydrolysis and/or utilization. Lachnospira pectinoschiza and L. multipara contain similar long-chain fatty acids (27), their cells are similar in size, and both organisms are mesophiles (4) (Table
4). L. pectinoschiza cells are peritrichous, form umbonate colonies, and have $\mathrm{G}+\mathrm{C}$ contents of 42 to $45 \mathrm{~mol} \%$. $L$. multipara cells are monotrichous, form flat, filamentous colonies (4), and have a $\mathrm{G}+\mathrm{C}$ content of $32 \mathrm{~mol} \%$. Both species produce acetate, formate, ethanol, methanol, and $\mathrm{CO}_{2}$ when they are grown on media that contain pectin. $L$. multipara also forms lactate and $\mathrm{H}_{2}$ (4). Devereux et al. (9) used the following formula to express the relationship between levels of rRNA similarity $(S)$ and DNA relatedness (\%DNA): $\log _{10} S=0.0350\left(\log _{10} \% \mathrm{DNA}\right)-0.0698$. When this formula was used, a DNA relatedness value of $17 \%$ was obtained for strain $150-1^{\mathrm{T}}$ and L. multipara. However, this value is only an estimate, and the exact relationship between rRNA and genomic sequence divergence probably varies between groups of microorganisms (3). In keeping with the proposal to balance phenotypic information and genetic information in nomenclature (37), we recommend that our strains should be placed in the genus Lachnospira.

Description of Lachnospira pectinoschiza sp. nov. Lachnospira pectinoschiza (pec'ti.no.schiz.a. M.L. n. pectinum, pectin; Gr. adj. schizon, splitting; M.L. fem. pectinoschiza, pectin splitting [40]). Cells grown in medium PF broth are rod shaped, 0.36 to $0.56 \mu \mathrm{m}$ wide, and 2.4 to $3.1 \mu \mathrm{m}$ long and are arranged singly, in pairs, or in chains containing three to six cells. Cells peritrichous and motile by means of 6 to 18 flagella per cell. Gram positive.

Colonies on medium PF agar are opaque, circular with wavy edges, umbonate, and 3 to $5 \mathrm{~mm}$ in diameter. Growth in medium containing PGA is rapid, with a doubling time of approximately $55 \mathrm{~min}$. Final cell yields are $2 \times 10^{9}$ to $3.5 \times$ $10^{9} \mathrm{CFU} / \mathrm{ml}$. Growth occurs at temperatures ranging from 30 to $45^{\circ} \mathrm{C}$. No growth occurs at 25 or $50^{\circ} \mathrm{C}$.

Obligate anaerobes. Growth requires a fermentable carbohydrate such as pectin, PGA, gluconic acid, lactose, or cellobiose. Fructose is used after a lag period of 2 to 6 days. The following compounds do not support growth: L-arabinose, D-galactose, D-glucose, D-glucuronate, glycogen, inositol, inulin, D-maltose, D-mannitol, D-mannose, D-raffinose, L-rhamnose, D-ribose, salicin, D-sorbitol, soluble starch, sucrose, trehalose, D-xylose, amino acids, arabinogalactan, carboxymethyl cellulose, cellulose, gum arabic, pig gastric mucin, and xylan. Catalase is not produced. Nitrate is not reduced. Esculin and gelatin are not hydrolyzed. Growth occurs in medium PF broth supplemented with $20 \%$ bile.

The major end products of PGA fermentation are formate and acetate; minor amounts of ethanol and $\mathrm{CO}_{2}$ are also formed. Methanol is formed when pectin is fermented.

Pectin is depolymerized by extracellular pectin methylesterase and a $\mathrm{Ca}^{2+}$-dependent exopectate lyase.

The $\mathrm{G}+\mathrm{C}$ content is $42 \mathrm{~mol} \%$, as determined by thermal denaturation.

Isolated from cecal and colonic contents of pigs. The type strain, strain 150-1, has been deposited in the American Type Culture Collection as strain ATCC 49827. 


\section{ACKNOWLEDGMENTS}

This research was supported in part by a research agreement between the Environmental Protection Agency and D.A.S.

We thank H. Cook, J. Goff, R. Morgan, J. Stasko, D. Lebo, R. Key, and B. Flesher for laboratory assistance and Steve Smith (Harvard University) for providing the GDE editor used for some of the sequence analysis described in this paper.

\section{REFERENCES}

1. Allison, M. J., K. A. Dawson, W. R. Mayberry, and J. G. Foss. 1985. Oxalobacter formigenes gen. nov., sp. nov.: oxalate degrading anaerobes that inhabit the gastrointestinal tract. Arch. Microbiol. 141:1-7.

2. Allison, M. J., I. M. Robinson, J. A. Bucklin, and G. D. Booth. 1979. Comparison of bacterial populations of the pig cecum and colon based upon enumeration with specific energy sources. Appl. Environ. Microbiol. 37:1142-1151.

3. Amann, R. I., C. Lin, R. Key, L. Montgomery, and D. A. Stahl. 1992. Diversity among Fibrobacter isolates: towards a phylogenetic classification. Syst. Appl. Microbiol. 15:23-31.

4. Bryant, M. P. 1986. Lachnospira, p. 1375-1376. In P. H. A. Sneath, N. S. Mair, M. E. Sharpe, and J. G. Holt (ed.), Bergey's manual of systematic bacteriology, vol. 2. Williams \& Wilkins Co., Baltimore.

5. Bryant, M. P., and L. A. Burkey. 1953. Cultural methods and some characteristics of some of the more numerous groups of bacteria in the bovine rumen. J. Dairy Sci. 36:205-217.

6. Butine, T. J., and J. A. Z. Leedle. 1989. Enumeration of selected anaerobic bacterial groups in cecal and colonic contents of growing-finishing pigs. Appl. Environ. Microbiol. 55:1112-1116.

7. Cerbulis, J. 1978. p-Anisidine-phosphoric acid as a color reagent for sugar derivatives and halogen compounds. J. Chromatogr. 155:226-228.

7a.Cornick, N. A., et al. 1990. Abstr. Annu. Meet. Am. Soc. Microbiol. 1990, Q146, p. 312.

8. DeSoete, G. 1973. A least-squares algorithm for fitting additive trees to proximity data. Psychometrika 48:621-626.

9. Devereux, R., S. He, C. L. Doyle, S. Orkland, D. A. Stahl, J. LeGall, and W. B. Whitman. 1990. Diversity and origin of Desulfovibrio species: phylogenetic definition of a family. J. Bacteriol. 172:3609-3619.

10. Doetsch, R. N. 1981. Determinative methods of light microscopy, p. 21-33. In P. Gerhardt, R. G. E. Murray, R. N. Costilow, E. W. Nester, W. A. Wood, N. R. Krieg, and G. B. Phillips (ed.), Manual of methods for general bacteriology. American Society for Microbiology, Washington, D.C.

11. Dowell, V. R., and G. L. Lombard. 1977. Presumptive identification of anaerobic nonsporeforming gram-negative bacilli. Centers for Disease Control, Atlanta.

12. Felsenstein, J. 1984. Confidence limits on phylogenies: an approach using the bootstrap. Evolution 39:783-791.

13. Holdeman, L. V., E. P. Cato, and W. E. C. Moore (ed.). 1977. Anaerobe laboratory manual, 4th ed. Virginia Polytechnic Institute and State University, Blacksburg.

14. Hull, I. A., R. E. Gill, P. Hsu, B. H. Minshew, and S. Falkow. 1981. Construction and expression of recombinant plasmids encoding type 1 or D-mannose-resistant pili from a urinary tract infection Escherichia coli isolate. Infect. Immun. 33:933-938.

15. Jensen, N. S., and E. Canale-Parola. 1986. Bacteroides pectinophilus sp. nov, and Bacteroides galacturonicus sp. nov.: two pectinolytic bacteria from the human intestinal tract. Appl. Environ. Microbiol. 52:880-887.

16. Jukes, T. H., and C. R. Cantor. 1969. Evolution of protein molecules, p. 21-132. In H. N. Munro (ed.), Mammalian protein metabolism. Academic Press, Inc., New York.

17. Kertesz, Z. I. 1957. Preparation and determination of pectic substances. Methods Enzymol. 3:27-30.

18. Koransky, J. R., S. D. Allen, and V. R. Dowell. 1978. Use of ethanol for selective isolation of sporeforming microorganisms. Appl. Environ. Microbiol. 35:762-765.

19. Laemmli, U. K. 1970. Cleavage of structural proteins during the assembly of the head of bacteriophage T4. Nature (London)
227:680-685.

20. Lane, D. J. 1991. 16S/23S rRNA sequencing, p. 115-175. In E. Stackebrandt and M. Goodfellow (ed.), Nucleic acid techniques in bacterial systematics. John Wiley \& Sons, Chichester, United Kingdom.

21. Lane, D. J., B. Pace, G. J. Olsen, D. A. Stahl, M. L. Sogin, and N. R. Pace. 1985. Rapid determination of 16S ribosomal RNA sequences for phylogenetic analyses. Proc. Natl. Acad. Sci. USA 82:6955-6959.

22. Leedle, J. A. Z., and R. B. Hespell. 1980. Differential carbohydrate media and anaerobic replica plating techniques in delineating carbohydrate-utilizing subgroups in rumen bacterial populations. Appl. Environ. Microbiol. 39:709-719.

23. Liu, Y. K., and B. S. Luh. 1978. Preparation and thin-layer chromatography of oligogalacturonic acids. J. Chromatogr. 151: $39-49$.

24. Mandel, M., and J. Marmur. 1968. Use of ultraviolet absorbance-temperature profile for determining the guanine plus cytosine content of DNA. Methods Enzymol. 12:195-206.

25. McComb, E. A., and R. M. McCready. 1958. Use of the hydroxamic acid reaction for determining pectinesterase activity. Stain Technol. 33:129-131.

26. Montgomery, L., B. Flesher, and D. A. Stahl. 1988. Transfer of Bacteroides succinogenes (Hungate) to Fibrobacter gen. nov. as Fibrobacter succinogenes comb. nov. and description of Fibrobacter intestinalis sp. nov. Int. J. Syst. Bacteriol. 38:430435.

27. Moore, W. E. C. (Virginia Polytechnic Institute and State University). 1992. Personal communication.

28. Nelson, N. 1944. A photometric adaptation of the Somogyi method for the determination of glucose. J. Biol. Chem. 153: $375-380$.

29. Olsen, J. O., N. Larsen, and C. R. Woese. 1991. The Ribosomal Database Project. Nucleic Acids Res. 19(Suppl.):2017-2021.

30. Pace, B., E. A. Matthews, K. K. Johnson, C. R. Cantor, and N. R. Pace. 1982. Conserved 5S rRNA complement to tRNA is not required for protein synthesis. Proc. Natl. Acad. Sci. USA 79:36-40.

31. Peterson, G. L. 1977. A simplification of the protein assay method of Lowry et al. which is more generally applicable. Anal. Biochem. 83:346-356.

32. Rexova-Benkova, L., and O. Markovic. 1976. Pectic enzymes. Adv. Carbohydr. Chem. 33:323-385.

33. Salanitro, J. P., and P. A. Muirhead. 1975. Quantitative method for the gas chromatographic analysis of short-chain monocarboxylic and dicarboxylic acids in fermentation media. Appl. Microbiol. 29:374-381.

34. Smibert, R. M., and J. A. Burmeister. 1983. Treponema pectinovorum sp. nov. isolated from humans with periodontitis. Int. J. Syst. Bacteriol. 33:852-856.

35. Stanton, T. B., and D. C. Savage. 1983. Roseburia cecicola gen. nov., sp. nov., a motile, obligately anaerobic bacterium from a mouse cecum. Int. J. Syst. Bacteriol. 33:618-627.

36. Swofford, D. L., and G. J. Olsen. 1990. Phylogeny reconstruction, p. 411-501. In D. M. Hillis and C. Moritz (ed.), Molecular systematics. Sinauer Associates, Sunderland, Mass.

37. Wayne, L. G., D. J. Brenner, R. R. Cowell, P. A. D. Grimont, O. Kandler, M. I. Krichevsky, L. H. Moore, W. E. C. Moore, R. G. E. Murray, E. Stackenbrandt, M. P. Starr, and H. G. Trüper. 1987. Report of the Ad Hoc Committee on Reconciliation of Approaches to Bacterial Systematics. Int. J. Syst. Bacteriol. 37:463-464.

38. Weber, F. H., and E. Canale-Parola. 1984. Pectinolytic enzymes of oral spirochetes from humans. Appl. Environ. Microbiol. 48:61-67.

39. Woese, C. R., R. Gutell, R. Gupta, and H. F. Noller. 1983. Detailed analysis of the higher-order structure of $16 \mathrm{~S}$-like ribosomal ribonucleic acids. Microbiol. Rev. 47:621-669.

40. Woods, R. S. 1966. An English-classical dictionary for the use of taxonomists. Pomona College Press, Pomona, Calif.

41. Ziolecki, A., and M. Wojciechowicz. 1980. Small pectinolytic spirochetes from the rumen. Appl. Environ. Microbiol. 39:919922. 